\title{
Leaf Morphological Plasticity of Tree Species from Two Developmental Stages in Araucaria Forest
}

\author{
Willyam de Lima Vieira ${ }^{1 *}$, Maria Regina Torres Boeger ${ }^{1}$, Nelson Luiz Cosmo ${ }^{1}$ and \\ Alessandra Ike Coan ${ }^{2}$ \\ ${ }^{I}$ Departamento de Botânica; Setor de Ciências Biológicas; Universidade Federal do Paraná; Curitiba - PR - Brasil. \\ ${ }^{2}$ Departamento de Botânica; Universidade Estadual Paulista "Júlio de Mesquita Filho"; Instituto de Biociências de \\ Rio Claro; Rio Claro - SP - Brasil
}

\begin{abstract}
This study compared the morphological and anatomical variations of the leaves of four shade-tolerant tree species Allophylus edulis (St.-Hil.) Radlk (Sapindaceae), Casearia sylvestris Sw. (Salicaceae), Cupania vernalis Cambess. (Sapindaceae) and Luehea divaricata Mart. (Malvaceae) from a fragment of Araucaria forest in two developmental stages. Morphological and anatomical traits, such as leaf and tissue thickness, leaf area, leaf dry mass, specific leaf area, leaf density and stomata density were measured from 30 leaves of each developmental stage. The phenotypic plasticity index was also calculated for each quantitative trait. The results showed that the four species presented higher mean values for specific leaf area and spongy/palisade parenchyma ratio at young stage, and higher mean values for stomata density, total and palisade parenchyma thickness in the adult stage. The plasticity index demonstrated that L. divricata presented highest plasticity for both the morphological and anatomical traits while A. edulis displayed the lowest plasticity index. The results of this study indicated that the leaves of these species exhibited distinct morphological traits at each stage of development to cope with acting environmental factors.
\end{abstract}

Key words: leaf anatomy, leaf morphology, Ombrophyllous Mist Forest, shade tolerance

\section{INTRODUCTION}

The tolerance of plants to shade is an important paradigm to understand the successional processes and the dynamic of tropical and temperate forests (Poorter 2009). Although the knowledge about the shade tolerance of the plants goes back to the 18th century, there are still controversies about what are the main morphological traits of tolerant species (Niinemets 2006). The knowledge about the adaptations to shade conditions is based mainly on the development of seedlings and the observed patterns are influenced by the interspecific variation of seed size (Sack et al. 2006; Valladares and Niinemets 2008).
Light availability is considered the most limited feature for the survival and growth of the plants (Chazdon and Fetcher 1984; Chazdon 1988). In tropical forests, only $2 \%$ of the canopy radiation reaches the forest soil (Chazdon 1988; Clark et al. 1996). In ombrophyllous forests, this light dynamic can be critical for the growth and development of the plant species tolerant to shade, favoring the development of different strategies, both temporal and spatial for their survival (Bloor and Grubb 2004).

The hypothesis of carbon gain (Givnish 1988) defines the shade tolerance of the plants as a maximization of light capture and its use in photosynthesis due to minimization of breathing

*Author for correspondence: limafilhovieira@gmail.com 
costs for survival. However, the tolerance to shade is associated to a large number of morphological anatomical features and even though many plants tolerate low light conditions, only a fraction of them can reproduce under these conditions (Valladares and Niinemets 2008). Plants that have greater morphological and anatomical adjustment to light conditions imposed by the environment have adaptive advantages, since the modifications can facilitate the exploration of new niches, resulting in an increase to light tolerance (Gratani et al. 2006).

Among the leaf morphological characteristics, leaf area, dry matter, specific leaf area, stomata density, and blade thickness are considered the most plastic features regarding light intensity variation (Gould 1993; Klich 2000; Boeger et al. 2004). Due to plasticity, these features are considered indicators of relative growth rate $\left(\mathrm{RGR}_{\max }\right)$ (Garnier and Laurent 1994) and of strategies of resource use (Vendramini et al. 2002). However, a crucial step towards understanding the ecological approaches the about plasticity is a quantitative estimation of the plastic changes induced by the environment (Valladares et al. 2006).

Accordingly, the phenotype-plasticity index (Valladares et al. 2000) has been used by many authors and is considered an important tool for understanding the occurrence and survival of the plant species in heterogeneous and variable environments such as ombrophylous forest (Balaguer et al. 2001; Gratani et al. 2003; Valladares et al. 2006).

Along a vertical gradient, the trees must go through a long way to reach canopy, facing a range of abiotic conditions. Such conditions also vary according to forest type and successional stage. Gaps, which represent an important facilitator of natural regeneration, may not occur. Many individuals need adjustments to heterogeneous light conditions in understory and it is expressed on leaf morphology (Niinemets 2006). However, morphological variations in the individuals the seedling and adult stages have been little explored. The existing studies about the leaf morphology versus vertical gradient have mainly investigated the seedlings and adult individuals comparatively (Rijkers et al. 2000; England and Attiwill 2006; Sanches et al. 2010). However, morphological and anatomical adjustments that tree species develop to transpose the vertical light gradient are also important for forest dynamic understanding (Klich 2000).

The morphological and anatomical differences between the seedlings and adult stages are wellknown and include higher specific leaf mass, lower leaf thickness and stomata density, and fewer layers of palisade parenchyma for the seedling stage. These characteristics increase the capacity of light absorption at the expense of photosynthetic capacity and minimize carbon losses through respiration (Rijkers et al. 2000).

However, as the seedlings grow toward the canopy, light availability and abiotic conditions change. This young stage is also very important for the plant growth due the investment to construct and maintain the supporting tissues as well the photosynthetic apparatus (Rijkers et al. 2000). For the shade tolerant species, this stage needs to adjust their leaf morphology to maximize the net carbon gain in low light (Valladares and Niinemets 2008).

The main objective of this study was to evaluate comparatively the leaf morphology and anatomy of representative tree species in Mixed Ombrophylous Forest between two developmental stages. The hypothesis was that that the leaf structure of these species was similar within the same stage, as they were influenced by the same local abiotic conditions. That meant that regardless of phylogenetic relation between the species, environmental conditions could determinate a morphological convergence. Seedling stage was omitted in this study, because it was a stage in which the development was more influenced by the seed reserves than by the local environment conditions (Ibarra-Manrìquez et al. 2001).

\section{MATERIALS AND METHODS}

Leaves were collected in a remnant of Araucaria Forest named "Capão do Tigre", located at Campus III of "Federal University of Paraná",

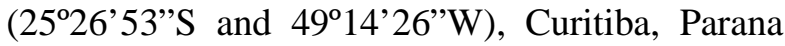
state, Brazil. This remnant has 15 ha in median to advanced stage of succession (Rondon Neto et al. 2002). The climate is classified as Cfb type, on Köppen's classification that means humid subtropical, mesothermic, with fresh summers and winter with frequent frosts, without dry season (Maack 1981). The soil type was classified as cambisoil (Rondon Neto et al. 2002). 
The median temperature of Curitiba for 2009 was $17.9^{\circ} \mathrm{C}$. The highest average temperature was $22.2^{\circ} \mathrm{C}$ in November, and the lowest average temperature was $12.5^{\circ} \mathrm{C}$ in June. The respective annual means of humidity and precipitation were $81 \%$ and $1662 \mathrm{~mm}$, respectively. September presented highest average precipitation (307.4 $\mathrm{mm})$ and April presented the lowest value (48 $\mathrm{mm}$ ) (Technological Institute SIMEPAR, PR) (Fig. 1).

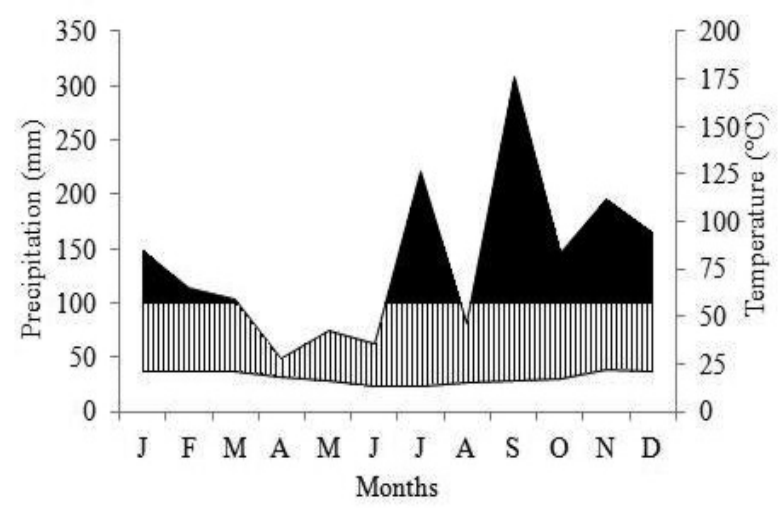

Figure 1 - Climatic diagram of the city of Curitiba, PR, year of 2009. Water period: Exceeding (-) and restitution/loss of water in the soil (IIII).

The light intensity of each stage was estimated with a light meter Li-250A (LICOR, USA). Ten measurements were made at noon during the plant collection in spring of 2009. The light measurements were taken in the same direction than the lamina surface.

The shade-tolerant trees, Allophylus edulis, Casearia sylvestris, Cupania vernalis and Luehea divaricata were selected based on the importance index (VI) and density of individuals (minimum of 10 individuals) on the studied area (Rondon Neto et al. 2002). For young stage, individuals up to $2 \mathrm{~m}$ to $4 \mathrm{~m}$ high were selected. Individuals over $8 \mathrm{~m}$ high were selected for adult stage. Total height was measured for all the selected individuals, with graduate ruler. The diameter at the breast height (DAP) was measured in all the adult individuals $(\mathrm{n}=10)$ and the diameter at the base stem height (DC) in all the young individuals $(n=15)$ with diametric meter.

Five and ten leaves, among $3^{\circ}$ and $6^{\circ}$ nodes from the apex were collected from the most external part of the canopy from the young and adult individual from each species. For compound leaves (A. edulis and C. vernalis), leaflets were collected and interpreted as simple leaves (Popma and Bongers 1988).

The thickness of fresh leaves was measured with a digital caliper and these data were used in leaf density calculation. Later, the same leaves were dried in the oven at $65^{\circ} \mathrm{C}$, until constant weight and the leaf dry weight (LDM, g) was estimated. For all the sampled leaves, the length (LL, mm) and width $(\mathrm{LW}, \mathrm{mm})$ were measured with digital caliper and the ratio of the length/width were calculated (LL/LW).

The leaf area $\left(\mathrm{LA}, \mathrm{cm}^{2}\right)$ was measured from the images created with a flatbed scanner calibrated with Sigma Scan PRO software (version 5.0, SPSS Inc., Chicago, IL, USA) and the specific leaf area (SLA, $\mathrm{cm}^{2} \mathrm{~g}^{-1}$ ) estimated by the leaf area/dry mass ratio. The leaf density ( $\mathrm{LD}, \mathrm{g} \mathrm{cm}^{-3}$ ) was estimated by the following formula: $\mathrm{LD}=$ SLM $* 1 / T L T$, where SLM = specific leaf mass ( $g$ $\mathrm{cm}^{-2}$ ) and TLT $=$ thickness. Stomata density (SD, $\mathrm{mm}^{2}$ ) was determined from the clear nail polish prints from the median region of epidermal surface of leaves and leaflets, using light microscope with coupled camera lucida. Two leaves from each by individual were used for the anatomical analysis. Leaves were fixed in FAA 70 (Johansen 1940) and then conserved in ethanol (70\%). The fixed samples were sectioned with razor blade, clarified in sodium hypochlorite $(10 \%)$, stained with toluidine blue $(1 \%)$ and mounted in glycerin and gelatin (Brito and Alquini 1996). In the transverse sections of the median regions of the leaf laminas, adaxial epidermis (DET, $\mu \mathrm{m}$ ) and abaxial epidermis $($ BET,$\mu \mathrm{m})$, palisade parenchyma (PPT, $\mu \mathrm{m}$ ), spongy parenchyma (SPT, $\mu \mathrm{m})$ and total thickness (TLT, $\mu \mathrm{m}$ ) were measured. The spongy parenchyma/palisade parenchyma ratio (SPT/PPT) was also calculated. All the measurements were made in optical microscope (Olympus CBB) with micrometric ocular. The mean values and respective standard deviations were calculated for all the quantitative variables of all species in both the developmental stages. The interspecific comparison between the stages and species were performed using a two-way ANOVA and the means were compared by Tukey's test, with $5 \%$ of significance using the software Statistica, version 7.0 (Statsoft Inc., USA). For all the species, the phenotypic plasticity index (IPF, sensu Valladares et al. 2000) was calculated, according to the following formula: IPF = (value of maximum mean - value of minimum mean) /(value of 
maximum mean) for each morphological and anatomical quantitative trait. This index varied between zero to one.

\section{RESULTS}

The highest mean height in the young stage was $1.35 \mathrm{~m}$, while in the adult stage, this was $10.55 \mathrm{~m}$ (Table 1). The highest mean diameter was $1.53 \mathrm{~cm}$ in the young stage and $13.6 \mathrm{~cm}$ in the adult stage. The photosynthetic active radiation (PAR) varied from $36.21 \pm 32.4$ in the young stage to $73.6 \pm 22.8$ $\mu \mathrm{mol} \mathrm{m} \mathrm{m}^{-2} \mathrm{~s}^{-1}$ in the adult stage, representing 1.60 and $3.25 \%$ of the canopy radiation, respectively.

Table 1 - Mean values and respective standard deviation of height $(\mathrm{m})$ and stem diameter at base of the stem $(\mathrm{DC}, \mathrm{cm})$ and/or at breast height (DAP, $\mathrm{cm})$ of young $(n=15)$ and adult individuals $(n=10)$ of the tree species studied.

\begin{tabular}{clcc}
\hline Traits & \multicolumn{1}{c}{ Species } & Young-stage & Adult-stage \\
\hline \multirow{3}{*}{ DAP/DC } & A. edulis & $1.53 \pm 0.22$ & $9.71 \pm 2.07$ \\
$(\mathrm{~cm})$ & C. sylvestris & $1.32 \pm 0.19$ & $12.87 \pm 2.03$ \\
& C. vernalis & $1.57 \pm 0.15$ & $10.38 \pm 1.07$ \\
& L. divaricata & $1.16 \pm 0.32$ & $13.57 \pm 1.73$ \\
& A. edulis & $1.35 \pm 0.22$ & $7.70 \pm 0.54$ \\
Height & C. sylvestris & $1.35 \pm 0.24$ & $10.30 \pm 0.67$ \\
$(\mathrm{~m})$ & C. vernalis & $1.31 \pm 0.14$ & $9.75 \pm 0.26$ \\
& L. divaricata & $1.03 \pm 0.15$ & $10.55 \pm 0.60$ \\
\hline
\end{tabular}

The two-way variance analysis showed that all the morphological and anatomical traits were different among the developmental stages and species, excluding LL/LW ratio and SPT between the stages. Also, all the morphological and anatomical traits presented interaction among the species and stages (Table 2), revealing significant differences in their plasticity response to light intensity.

Comparing the two stages of development, youngstage leaves presented higher mean values of LDM and LA (except $L$. divaricata and A. edulis), SLA for all the species and LL and LL/LW ratio only for $C$. vernalis. The SD and $\mathrm{LD}$ were higher in the adult stage for all the species, except LD in A. edulis (Table 3).

For the anatomical characteristics, SPT/PPT ratio was highest for all the species in the young stage. The DET mean values were highest in the young stage for $C$. sylvestris and for $L$. divaricata in the adult stage. In the adult stage, BET was highest only for $C$. sylvestris and SPT for $L$. divaricata. The mean values of PPT were highest in the adult stage leaves for all the species, except A. edulis. The TLT was similar between the stages for $C$. sylvestris and $C$. vernalis, and higher at adult stage for A. edulis and L. divaricata (Table 4).

Table 2 - Two-way analysis of variance of morphological and anatomical traits.

\begin{tabular}{llll}
\hline & \multicolumn{1}{c}{ F e $(\mathbf{P})$-values } & \\
\cline { 2 - 4 } Traits & Developmental stages & Species & Interaction \\
\hline LDM $(\mathrm{g})$ & $21.823(<0.0001)$ & $272.026(<0.0001)$ & $163.317(<0.0001)$ \\
LA $\left(\mathrm{cm}^{2}\right)$ & $34.365(<0.0001)$ & $306.924(<0.0001)$ & $68.947(<0.0001)$ \\
SLA $\left(\mathrm{cm}^{2} \mathrm{~g}^{-1}\right)$ & $1057.090(<0.0001)$ & $845.382(<0.0001)$ & $368.730(<0.0001)$ \\
LD $\left(\mathrm{g} \mathrm{cm}^{-3}\right)$ & $185.440(<0.0001)$ & $228.044(<0.0001)$ & $64.576(<0.0001)$ \\
LL $(\mathrm{mm})$ & $71.748(<0.0001)$ & $146.318(<0.0001)$ & $49.042(<0.0001)$ \\
LW $(\mathrm{mm})$ & $44.288(<0.0001)$ & $623.604(<0.0001)$ & $54.735(<0.0001)$ \\
LL/LW ratio & $0.754(0.3856) \mathrm{n} . \mathrm{s}$ & $288.586(<0.0001)$ & $68.350(<0.0001)$ \\
SD $\left(\mathrm{n}^{\circ} \mathrm{mm}{ }^{2}\right)$ & $820.574(<0.0001)$ & $263.407(<0.0001)$ & $29.509(<0.0001)$ \\
TLT $(\mu \mathrm{m})$ & $112.833(<0.0001)$ & $197.881(<0.0001)$ & $25.631(<0.0001)$ \\
DET $(\mu \mathrm{m})$ & $5.326(0.0219)$ & $62.556(<0.0001)$ & $50.000(<0.0001)$ \\
BET $(\mu \mathrm{m})$ & $13.587(0.0003)$ & $60.267(<0.0001)$ & $12.850(<0.0001)$ \\
PPT $(\mu \mathrm{m})$ & $508.368(<0.0001)$ & $20.569(<0.0001)$ & $17.810(<0.0001)$ \\
SPT $(\mu \mathrm{m})$ & $0.005(0.9417) \mathrm{n} . \mathrm{s}$ & $353.684(<0.0001)$ & $16.658(<0.0001)$ \\
SPT/PPT ratio & $352.282(<0.0001)$ & $201.964(<0.0001)$ & $55.019(<0.0001)$ \\
\hline
\end{tabular}

Legends: Leaf dry mass (LDM), leaf area (LA), specific leaf area (SLA), leaf density (LD), leaf length (LL), leaf width (LW), stomata density (SD), total leaf thickness (TLT), adaxial epidermis thickness (DET), abaxial epidermis thickness (BET), palisade parenchyma thickness (PPT), spongy parenchyma thickness (SPT). Significant differences by Tukey's test $(\mathrm{P}<0.05$, n.s. not significant). 
Table 3 - Mean values and respective standard deviations of leaf morphological traits of studied species, from two developmental stages.

\begin{tabular}{|c|c|c|c|c|c|}
\hline \multirow[b]{2}{*}{ Traits } & \multirow[b]{2}{*}{ Stages } & \multicolumn{4}{|c|}{ Species } \\
\hline & & A. edulis & C. sylvestris & C. vernalis & L. divaricata \\
\hline \multirow[t]{2}{*}{ LDM (g) } & Young & $0.09 \pm 0.04^{\mathrm{b}}$ & $0.17 \pm 0.04^{\mathrm{a}}$ & $0.37 \pm 0.09^{\mathrm{a}}$ & $0.11 \pm 0.04^{\mathrm{b}}$ \\
\hline & Adult & $0.10 \pm 0.03^{\mathrm{a}}$ & $0.13 \pm 0.04^{\mathrm{b}}$ & $0.27 \pm 0.11^{\mathrm{b}}$ & $0.36 \pm 0.13^{\mathrm{a}}$ \\
\hline \multirow[t]{2}{*}{$\mathrm{LA}\left(\mathrm{cm}^{2}\right)$} & Young & $25.55 \pm 9.44^{\mathrm{a}}$ & $26.39 \pm 4.60^{\mathrm{a}}$ & $47.78 \pm 9.85^{\mathrm{a}}$ & $43.73 \pm 11.91^{\mathrm{a}}$ \\
\hline & Adult & $22.14 \pm 5.88^{\mathrm{b}}$ & $15.30 \pm 3.75^{\mathrm{b}}$ & $29.35 \pm 11.13^{b}$ & $57.29 \pm 19.59^{\mathrm{a}}$ \\
\hline \multirow[t]{2}{*}{$\operatorname{SLA}\left(\mathrm{cm}^{2} \mathrm{~g}^{-1}\right)$} & Young & $274.34 \pm 26.99^{\mathrm{a}}$ & $155.78 \pm 17.90^{\mathrm{a}}$ & $132.92 \pm 22.59^{\mathrm{a}}$ & $393.24 \pm 66.41^{\mathrm{a}}$ \\
\hline & Adult & $227.00 \pm 36.20^{\mathrm{b}}$ & $120.16 \pm 17.37^{\mathrm{b}}$ & $113.02 \pm 15.83^{b}$ & $164.26 \pm 38.43^{b}$ \\
\hline \multirow[t]{2}{*}{$\operatorname{LD}\left(\mathrm{g} \mathrm{cm}^{-3}\right)$} & Young & $0.69 \pm 0.20^{\mathrm{a}}$ & $0.56 \pm 0.11^{\mathrm{b}}$ & $0.50 \pm 0.09^{b}$ & $0.28 \pm 0.04^{\mathrm{b}}$ \\
\hline & Adult & $0.61 \pm 0.10^{\mathrm{b}}$ & $0.73 \pm 0.07^{\mathrm{a}}$ & $0.66 \pm 0.11^{\mathrm{a}}$ & $0.48 \pm 0.09^{\mathrm{a}}$ \\
\hline \multirow[t]{2}{*}{$\mathrm{LL}(\mathrm{mm})$} & Young & $118.58 \pm 26.05^{\mathrm{a}}$ & $99.08 \pm 9.91^{\mathrm{a}}$ & $146.55 \pm 18.57^{\mathrm{a}}$ & $123.66 \pm 18.68^{b}$ \\
\hline & Adult & $108.21 \pm 17.13^{\mathrm{a}}$ & $84.60 \pm 11.43^{\mathrm{a}}$ & $108.63 \pm 22.30^{b}$ & $136.32 \pm 24.52^{\mathrm{a}}$ \\
\hline \multirow[t]{2}{*}{ LW (mm) } & Young & $40.14 \pm 6.60^{\mathrm{a}}$ & $39.98 \pm 3.33^{\mathrm{a}}$ & $44.85 \pm 4.99^{\mathrm{a}}$ & $60.12 \pm 9.13^{\mathrm{a}}$ \\
\hline & Adult & $38.34 \pm 4.95^{\mathrm{b}}$ & $27.52 \pm 3.55^{\mathrm{a}}$ & $37.81 \pm 6.40^{\mathrm{a}}$ & $66.78 \pm 12.77^{\mathrm{a}}$ \\
\hline \multirow[t]{2}{*}{ LL/LW ratio } & Young & $2.95 \pm 0.34^{\mathrm{a}}$ & $2.48 \pm 0.21^{\mathrm{b}}$ & $3.29 \pm 0.41^{\mathrm{a}}$ & $2.08 \pm 0.29^{\mathrm{a}}$ \\
\hline & Adult & $2.83 \pm 0.35^{\mathrm{a}}$ & $3.10 \pm 0.39^{\mathrm{a}}$ & $2.88 \pm 0.36^{\mathrm{b}}$ & $2.07 \pm 0.30^{\mathrm{a}}$ \\
\hline \multirow[t]{2}{*}{$\mathrm{SD}\left(\mathrm{n}^{\circ} \mathrm{mm}^{2}\right)$} & Young & $219.39 \pm 32.46^{\mathrm{b}}$ & $389.09 \pm 96.06^{\mathrm{b}}$ & $465.15 \pm 74.10^{\mathrm{b}}$ & $366.06 \pm 54.86^{\mathrm{b}}$ \\
\hline & Adult & $382.27 \pm 65.04^{\mathrm{a}}$ & $725.45 \pm 125.40^{\mathrm{a}}$ & $627.50 \pm 113.29^{a}$ & $571.82 \pm 122.91^{\mathrm{a}}$ \\
\hline
\end{tabular}

Legends: Leaf dry mass (LDM), leaf area (LA), specific leaf area (SLA), leaf density (LD), leaf length (LL), leaf width (LW), stomata density (SD). Different letters represent significant differences between stages by Tukey's test $(\mathrm{P}<0.05)$.

Table 4 - Mean values and respective standard deviations of leaf anatomical traits of studied species, from two developmental stages.

\begin{tabular}{|c|c|c|c|c|c|}
\hline \multirow{2}{*}{ Traits } & \multirow{2}{*}{ Stages } & \multicolumn{4}{|c|}{ Species } \\
\hline & & A. edulis & C. sylvestris & C. vernalis & L. divaricata \\
\hline \multirow[t]{2}{*}{ TLT $(\mu \mathrm{m})$} & Young & $84.24 \pm 9.55^{b}$ & $141.38 \pm 14.88^{\mathrm{a}}$ & $107.58 \pm 7.00^{\mathrm{a}}$ & $61.30 \pm 5.47^{b}$ \\
\hline & Adult & $98.42 \pm 18.58^{\mathrm{a}}$ & $145.41 \pm 19.49^{\mathrm{a}}$ & $121.61 \pm 14.79^{\mathrm{a}}$ & $108.90 \pm 18.98^{\mathrm{a}}$ \\
\hline \multirow[t]{2}{*}{ DET $(\mu \mathrm{m})$} & Young & $16.03 \pm 1.77^{\mathrm{a}}$ & $19.50 \pm 0.00^{\mathrm{a}}$ & $19.50 \pm 0.00^{\mathrm{a}}$ & $17.02 \pm 1.84^{\mathrm{b}}$ \\
\hline & Adult & $16.03 \pm 2.02^{\mathrm{a}}$ & $15.41 \pm 1.40^{\mathrm{b}}$ & $21.70 \pm 2.87^{\mathrm{a}}$ & $21.21 \pm 3.06^{\mathrm{a}}$ \\
\hline \multirow[t]{2}{*}{$\mathrm{BET}(\mu \mathrm{m})$} & Young & $12.46 \pm 1.81^{\mathrm{a}}$ & $9.75 \pm 0.00^{b}$ & $9.75 \pm 0.00^{\mathrm{a}}$ & $8.39 \pm 1.66^{\mathrm{a}}$ \\
\hline & Adult & $10.48 \pm 1.40^{\mathrm{a}}$ & $10.61 \pm 1.28^{\mathrm{a}}$ & $8.39 \pm 1.66^{\mathrm{a}}$ & $8.26 \pm 1.59^{\mathrm{a}}$ \\
\hline \multirow[t]{2}{*}{$\mathrm{PPT}(\mu \mathrm{m})$} & Young & $22.08 \pm 3.15^{\mathrm{a}}$ & $22.10 \pm 4.39^{b}$ & $29.90 \pm 2.47^{\mathrm{a}}$ & $13.07 \pm 1.88^{\mathrm{b}}$ \\
\hline & Adult & $36.38 \pm 8.91^{\mathrm{a}}$ & $43.29 \pm 8.20^{\mathrm{a}}$ & $44.89 \pm 10.85^{\mathrm{a}}$ & $43.78 \pm 9.27^{\mathrm{a}}$ \\
\hline \multirow[t]{2}{*}{$\mathrm{SPT}(\mu \mathrm{m})$} & Young & $33.79 \pm 6.92^{\mathrm{a}}$ & $89.05 \pm 13.96^{\mathrm{a}}$ & $48.10 \pm 6.24^{\mathrm{a}}$ & $23.06 \pm 3.59^{\mathrm{b}}$ \\
\hline & Adult & $35.52 \pm 10.49^{\mathrm{a}}$ & $76.10 \pm 13.56^{\mathrm{a}}$ & $46.62 \pm 8.61^{\mathrm{a}}$ & $35.40 \pm 10.85^{\mathrm{a}}$ \\
\hline \multirow[t]{2}{*}{$\mathrm{SPT} / \mathrm{PPT}$ ratio } & Young & $1.55 \pm 0.36^{\mathrm{a}}$ & $4.17 \pm 0.98^{\mathrm{a}}$ & $1.62 \pm 0.24^{\mathrm{a}}$ & $1.79 \pm 0.32^{\mathrm{a}}$ \\
\hline & Adult & $0.99 \pm 0.22^{b}$ & $1.80 \pm 0.35^{\mathrm{b}}$ & $1.12 \pm 0.43^{b}$ & $0.82 \pm 0.24^{\mathrm{b}}$ \\
\hline
\end{tabular}

Legends: Total leaf thickness (TLT), adaxial epidermis thickness (DET), abaxial epidermis thickness (BET), palisade parenchyma thickness (PPT), spongy parenchyma (SPT). Different letters represent significant differences between stages by Tukey's test $(\mathrm{P}<0.05)$.

There was a predominance of one layer of palisade parenchyma in the young stage (Figs. 2 A, C, E and $\mathrm{G})$, while in the adult stage, the number of layers varied between one and two layers (Figs. 2 $\mathrm{B}, \mathrm{D}, \mathrm{F}$ and $\mathrm{H}$ ). The spongy parenchyma in the young stage varied from two to five layers (Figs. 2 $\mathrm{A}, \mathrm{C}, \mathrm{E}$ and $\mathrm{G}$ ). In the adult stage, this tissue varied from three to nine layers (Figs. $2 \mathrm{~B}, \mathrm{D}, \mathrm{F}$ and $\mathrm{H}$ ). Adult stage of $C$. vernalis and $L$. divaricata presented spongy parenchyma more compacted (Figs. $2 \mathrm{~F}$ and $\mathrm{H}$ ).

$L$. divaricata had the highest IPF, including both the morphological and anatomical traits. A. edulis showed the lowest IPF for the morphological characteristics and $C$. vernalis for the anatomical characteristics (Table 5). 

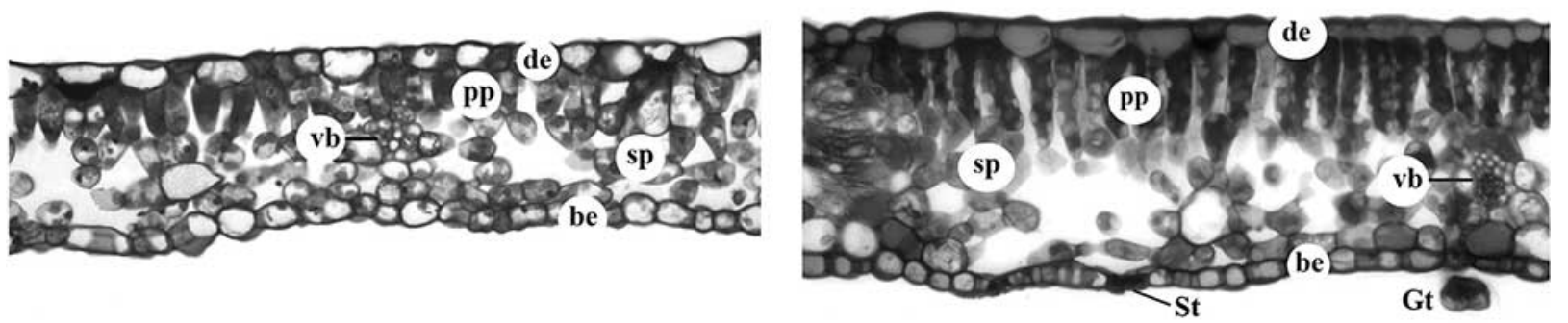

A

B

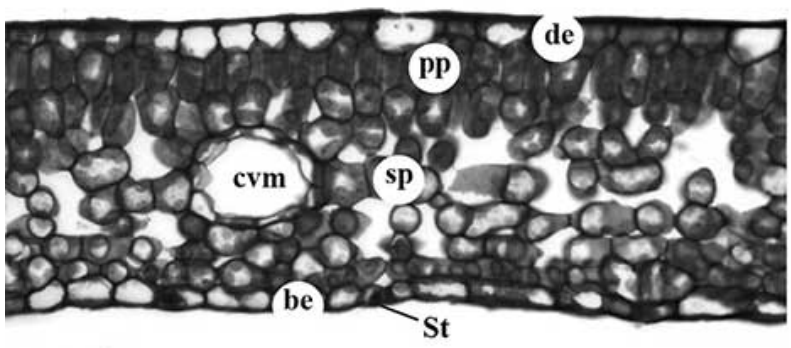

C
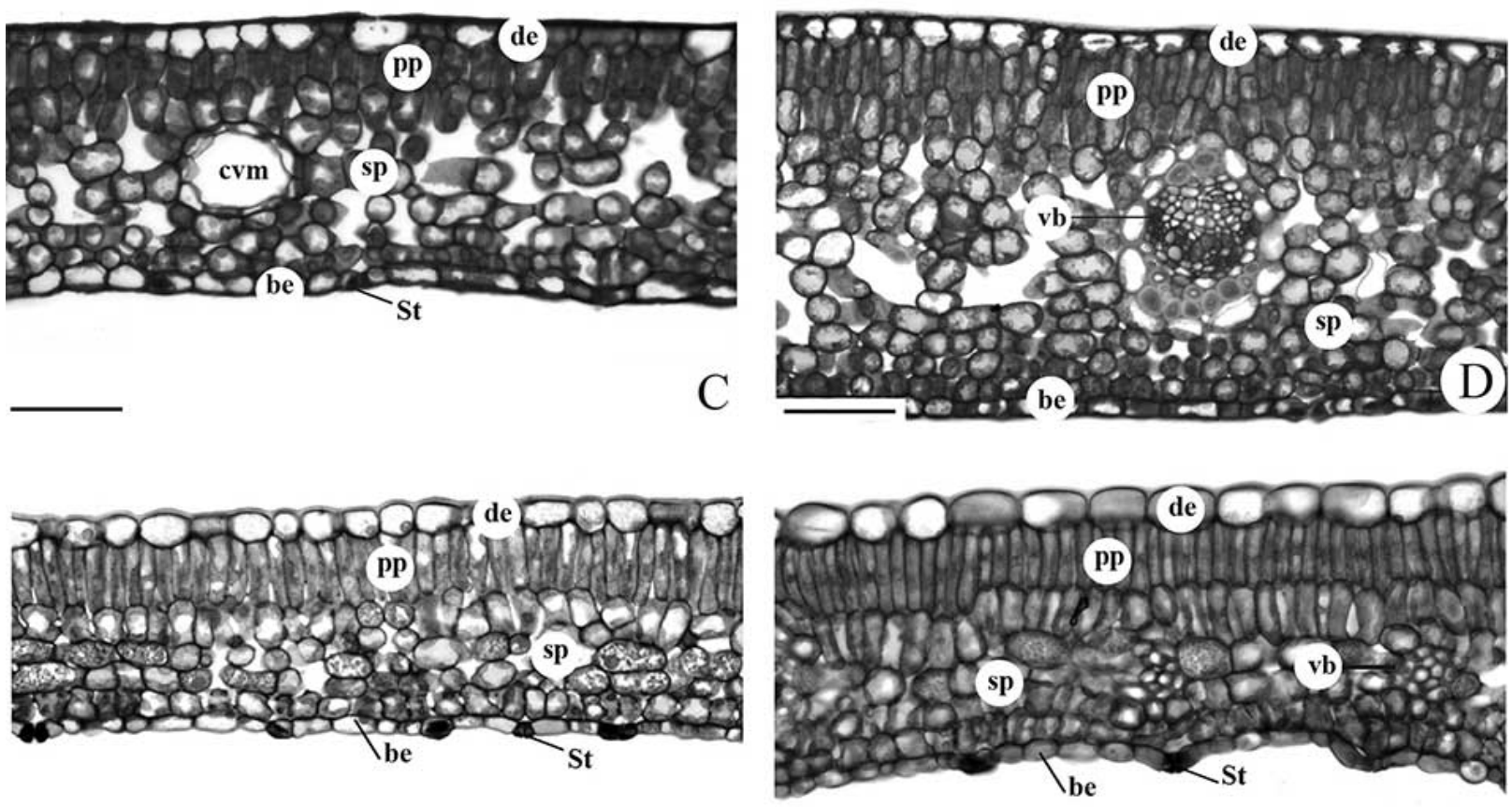

E

F
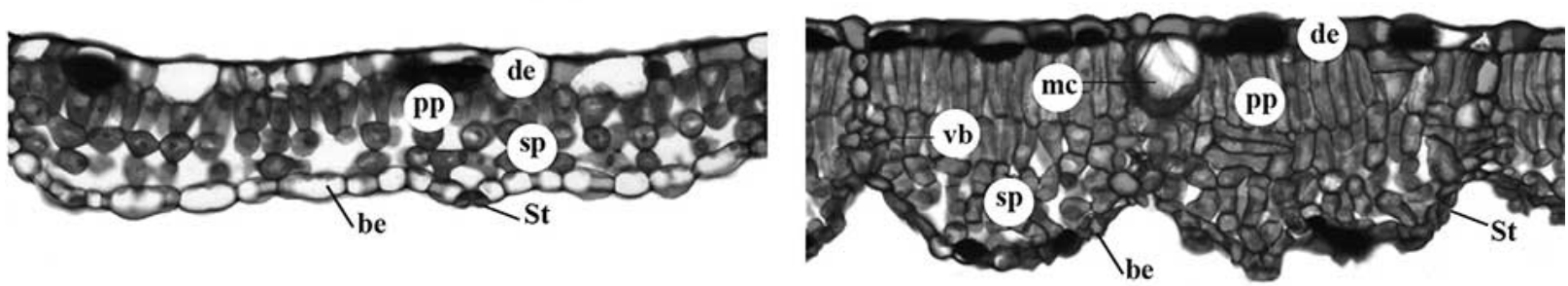

G

Figure 2 - Leaf transverse sections of species studied in two developmental stages. Young (A, C, E, G) and adult stages (B, D, F, H). Allophylus edulis (A, B), Casearia sylvestris (C, D), Cupania vernalis $(\mathrm{E}, \mathrm{F})$ and Luehea divaricata $(\mathrm{G}, \mathrm{H})$. (de = adaxial epidermis; be = abaxial epidermis; $\mathrm{pp}=$ palisade parenchyma; $\mathrm{sp}=$ spongy parenchyma; $\mathrm{cvm}=$ cavity in the mesophyll; $\mathrm{St}=$ stomata $\mathrm{Gt}=$ glandular trichome; $\mathrm{mc}=$ monocrystals of calcium oxalate; $v b=$ vascular bundles). Bar $=50 \mu \mathrm{m}$. 
Table 5 - Phenotypic plasticity index (IPF) of morphological and anatomical traits of the four studied species.

\begin{tabular}{|c|c|c|c|c|}
\hline \multirow[b]{2}{*}{ Traits } & \multicolumn{4}{|c|}{ Species } \\
\hline & $\begin{array}{c}\text { A. } \\
\text { edulis }\end{array}$ & $\begin{array}{c}C . \\
\text { sylvestris }\end{array}$ & $\begin{array}{c}C . \\
\text { vernalis }\end{array}$ & $\begin{array}{c}L . \\
\text { divaricata }\end{array}$ \\
\hline LDM (g) & 0.10 & 0.24 & 0.27 & 0.69 \\
\hline $\mathrm{LA}\left(\mathrm{cm}^{2}\right)$ & 0.13 & 0.42 & 0.39 & 0.24 \\
\hline $\operatorname{SLA}\left(\mathrm{cm}^{2} \mathrm{~g}^{-1}\right)$ & 0.17 & 0.23 & 0.15 & 0.58 \\
\hline $\operatorname{LD}\left(\mathrm{g} \mathrm{cm}^{-3}\right)$ & 0.12 & 0.23 & 0.24 & 0.42 \\
\hline LL (mm) & 0.09 & 0.15 & 0.26 & 0.09 \\
\hline $\mathrm{LW}(\mathrm{mm})$ & 0.04 & 0.31 & 0.16 & 0.10 \\
\hline $\mathrm{LL} / \mathrm{LW}$ ratio & 0.04 & 0.20 & 0.12 & 0.00 \\
\hline IPF mean & 0.10 & 0.25 & 0.23 & 0.30 \\
\hline $\mathrm{SD}\left(\mathrm{n}^{\circ} \mathrm{mm}^{2}\right)$ & 0.43 & 0.49 & 0.26 & 0.36 \\
\hline $\operatorname{TLT}(\mu \mathrm{m})$ & 0.14 & 0.03 & 0.12 & 0.44 \\
\hline $\operatorname{DET}(\mu \mathrm{m})$ & 0.00 & 0.21 & 0.10 & 0.20 \\
\hline $\mathrm{BET}(\mu \mathrm{m})$ & 0.16 & 0.08 & 0.14 & 0.02 \\
\hline PPT $(\mu \mathrm{m})$ & 0.39 & 0.49 & 0.33 & 0.70 \\
\hline $\mathrm{SPT}(\mu \mathrm{m})$ & 0.05 & 0.15 & 0.03 & 0.35 \\
\hline SPT/PPT ratio & 0.36 & 0.57 & 0.31 & 0.54 \\
\hline IPF mean & 0.22 & 0.29 & 0.18 & 0.37 \\
\hline
\end{tabular}

Legends: Leaf dry mass (LDM), leaf area (LA), specific leaf area (SLA), leaf density (LD), leaf length (LL), leaf width (LW), stomata density (SD), total leaf thickness (TLT), adaxial epidermis thickness (DET), abaxial epidermis thickness (BET), palisade parenchyma thickness (PPT), spongy parenchyma thickness (SPT)

\section{DISCUSSION}

The results supported only partially the morphological premises described for the understory plants, including thin leaves with lower dry matter and stomata density, higher leaf area and specific leaf area, when compared to canopy leaves or the plants with higher light availability (Givnish 1988; Popma and Bongers 1988; Valladares et al. 2002; Johnson et al. 2005; Rozendaal et al. 2006; Kitajima and Poorter 2010). The dry matter did not follow the expected pattern, because young stage leaves presented higher dry matter than the adult stage leaves, except $L$. divaricata. The dry matter was mainly influenced by higher leaf areas in the understory leaves, likely because larger leaf surfaces in the environments with lower light availability maximized the capture of diffused light in the forest (Valladares et al. 2002; Panditharathna et al. 2008; Valladares and Niinemets 2008).

The lower leaf areas and dry matters did not corroborate higher leaf density data found in the adult stage leaves. Leaf density, which represented the relationship among the dry matter, leaf area and thickness (Witkowski and Lamont 1991), was higher for every adult-stage species, except $A$. edulis. The higher leaf density in this stage seemed to be defined mainly by the leaf thickness, especially in $C$. vernalis and $L$. divaricata leaves. In the latter, leaf density was doubled in the adult stage, according to observed significant thickness raise $(54 \%)$.

The simultaneous increase in the leaf density and thickness might cause modifications on the leaf anatomy, leading to limitation of gases diffusion into the blade (Niinemets 1999). As light becomes more available, the leaves tend to produce smaller leaf surfaces and increment the thickness (mainly the palisade parenchyma) for a more efficient canalized light capture (Hanba et al. 2002; LakuŠić et al. 2006; Sanches et al. 2010).

SLA and stomata density followed the expected trend and they were the only variables, which showed the higher values in the young stages for studied species. The high SLA values $\left(>130 \mathrm{~cm}^{2}\right.$ $\mathrm{g}^{-1}$ ) in the young stage indicated a higher investment in the photosynthetic tissues regarding the mechanical tissues, since these species were in growth stage, seeking for better light conditions in the canopy or close to it (Poorter 1999; Boeger et al. 2006; England and Attiwill 2006).

The young stage leaves presented lower stomata density than the adult stage leaves per area unit probably due to more xeric conditions of the layer near the canopy. The higher number of stomata per unit of area in the adult stage leaves compensated the shorter time the stomata were open due to higher water stress in this layer (Pearcy et al. 2005; Sanches et al. 2010). However, stomata density seemed to be an inherent characteristic of all the studied species, not selected by the environmental pressures. In the adult stage of $A$. edulis, the mean values of stomata density were similar to stomata average in the young leaves from other studied species (C. sylvestris and $L$. divaricata).

The palisade parenchyma thickness varied more than spongy parenchyma between the stages, as observed in the ratio spongy/palisade parenchyma. In the adult stage, two species (A. edulis and $L$. divaricata) showed a ratio $<1$, due to an expressive palisade parenchyma increment in the adult stage, mainly in $L$. divaricata (44\%), as observed in other studies (Vogelmann et al. 1996; Cao 2000; Lee et al. 2000; Hanba et al. 2002; Sanches et al. 2010).

As expected, every species showed a spongy/palisade parenchyma ratio $>1$ in the young stages. This result indicated the importance of 
spongy parenchyma in diffused light capturing process in understory. In the environments with lower light availability, as in the forest, a thicker spongy parenchyma becomes an advantage to capture the diffused light due to irregular cell shape (Vogelmann et al. 1996).

The ombrophylous forests are highly heterogeneous concerning solar radiation; therefore, the plants are under different light intensity along the day and the seasons (Pearcy 2007). This environment complexity regarding the luminosity seemed to create a mosaic of morphological and anatomical responses throughout a light gradient, evidenced by plasticity indices values.

The plasticity indices (IPF) (sensu Valladares et al. 2006) were higher to anatomical characteristics but in $C$. vernalis, which had higher IPF values to the morphological characteristics. The attribute that most contributed to higher IPF values for the anatomical characteristics, besides stomata density, was the thickness of the palisade parenchyma and, consequently, the SP/PP ratio. Markesteijn et al. (2007) found similar results to IPF values for 43 species of dry tropical Forest.

Among the morphological characteristics, leaf area (in $C$. sylvestris and $C$. vernalis) and specific leaf area (in $A$. edulis and $L$. divaricata) presented higher IPF values. These results corroborated with other studies suggesting that depending on the environmental factors, some characteristics were more plastic than others (Valladares et al. 2000; Gratani et al. 2006; Rozendaal et al. 2006). The leaf area, specific leaf area, stomata density and tissues thickness are dependent of light intensity and relative air humidity variations (Cao 2000; Lee et al. 2000; Hanba et al. 2002) due to necessary adjustments on leaf structure to keep the balance between the water losses via respiration and carbon gains via photosynthesis (Givnish 1988).

The plastic responses, measured by IPF, have important implications concerning the ecological dynamics, providing evidences of adaptation and niche occupation differentiation in coexisting plant species (Xu et al. 2009). Furthermore, these responses also enable to identify the tendencies in successional processes. The studied species are classified as early secondary (Vaccaro et al. 1999; Santos et al. 2004) that is, they settle in the shaded environments but could benefit from the clearing gaps. For this, they must have higher capacity to morphological adjustments to light conditions in each stratum.

\section{CONCLUSIONS}

The results supported partially the previous findings described for the understory plants related to leaf morphology: large leaf area, low dry matter, specific leaf area and stomata density, and thin blade. Among the analyzed morphological and anatomical traits, the leaf thickness, dry matter, stomata density, leaf area, and specific leaf area fitted the expected pattern for the young stage plants. For the adult stage leaves, leaf area and stomata density for some species did not follow the previous reports. This variation among the species and stages appeared to be a response to the highly heterogeneity of environmental conditions, especially irradiation in the forest along the day and seasons. The complex environment regarding to light creates a mosaic of leaves with different morphological and anatomical responses. The plasticity index showed this mosaic, especially for the anatomical characteristics. These traits have higher index values than the morphological ones, indicating that the leaf anatomy is more light dependent than the leaf morphology. The observed plastic responses have important ecological meanings, such as niche occupation differentiation in coexistent plant species and successional dynamics.

\section{ACKOWLEDGEMENTS}

The authors are grateful to "Coordenação de Aperfeiçoamento de Pessoal de Nível Superior" (CAPES) for scholarship to the first author; to "Conselho Nacional de Desenvolvimento Científico e Tecnológico" (CNPq) for financial support (process $\mathrm{n}^{\circ}$. 470556/2009-9) and the productivity fellowship to the second author (process $n^{\circ}$. 309386/2007-1).

\section{REFERENCES}

Balaguer L, Martínez-Ferri E, Valladares F, PérezCorona E, Baquedano FJ, Castillo FJ, Manrique E. Population divergence in the plasticity of the response of Quercus coccifera to the light environment. Funct Ecol. 2001; 15: 124-135. 
Bloor JMG, Grubb PJ. Morphological plasticity of shade-tolerant tropical rainforest tree seedlings exposed to light changes. Funct Ecol. 2004; 18: 337348.

Boeger MRT, Alves LC, Negrelle RRB. Leaf morphology of 89 tree species from a Lowland Tropical Rain Forest (Atlantic Forest) in South Brazil. Braz Arch Biol Technol. 2004; 47(6): 933943.

Boeger MRT, Kaehler M, Melo JCF, Gomes MZ, Oliveira LS, Chaves CRM, Schottz ES. Estrutura foliar de seis espécies do subosque de um remanescente de Floresta Ombrófila Mista. Hoehnea. 2006; 33: 521-531.

Brito JFA, Alquini Y. A new method for staining botanical material embedded in glycol methacrylate (GMA). Braz Arch Biol Technol. 1996; 39: 949-951.

Cao KF. Leaf anatomy and chlorophyll content of 12 woody species in contrasting conditions in a Bornean heath Forest. Can J Bot. 2000; 78: 1245-1253.

Chazdon RL, Fetcher N. Photosynthetic light environments in a lowland tropical rain forest in Costa Rica. J Ecol. 1984; 72: 553-564.

Chazdon RL. Sunflecks in the forest understory. $A d v$ Ecol Res. 1988; 18: 1-63.

Clark DB, Clark DA, Rich PM, Weiss S, Oberbauer SF. Landscape-scale evaluation of understory light and canopy structure: methods and application in a neotropical lowland rain forest. Can J Forest Res. 1996; 26: 747-757.

England JR, Attiwill PM. Changes in leaf morphology and anatomy with tree age and height in the broadleaved evergreen species, Eucalyptus regnans F. Muell. Trees Struct Funct. 2006; 20: 79-90.

Garnier E, Laurent G. Leaf anatomy, specific mass and water content in congeneric annual and perennial grass species. New Phytol. 1994; 128: 725-736.

Givnish TJ. Adaptation to sun and shade: a whole-plant perspective. Aust J Plant Physiol. 1988; 15: 63-92.

Gould KS. Leaf heteroblasty in Pseudopanax crassifolius: functional significance of leaf morphology and anatomy. Ann Botany. 1993; 71: 6170.

Gratani L, Covone F, Larcher W. Leaf plasticity in response to light of three evergreen species of the Mediterranean maquis. Trees Struct Funct. 2006; 20: 549-558.

Gratani L, Meneghini M, Pesoli P, Crescente MF. Structural and functional plasticity of Quercus ilex seedlings of different provenances in Italy. Oecol. 2003; 17: 515-521.

Hanba YT, Kogami H, Terashima I. The effect of growth irradiance on leaf anatomy and photosynthesis in Acer species differing in light demand. Plant Cell Environ. 2002; 25: 1021-1030.

Ibarra-Manríquez G, Ramos MM, Oyama K. Seedling functional types in a lowland rain forest in Mexico. Am J Bot. 2001; 88: 1801- 812.
Johansen, D.A. Plant Microtechnique. New York: McGraw Hill; 1940.

Johnson DM, Smith WK, Vogelmann TC, Brodersen C. Leaf architecture and direction of incident light influence mesophyll fluorescence profiles. Am J Bot. 2005; 92: 1425-1431.

Kitajima K, Poorter L. Tissue-level leaf toughness, but not lamina thickness, predicts sapling leaf lifespan and shade tolerance of tropical tree species. New Phytol. 2010; 186: 708-721.

Klich MG. Leaf variations in Elaeagnus angustifolia related to environmental heterogeneity. Environ Exp Bot. 2000; 44: 171-183.

Lakušić B, Lakušić D, Jančić R, Stevanović B. Morpho-anatomical differentiation of the balkan populations of the species Teucrium flavum L. (Lamiaceae). Flora. 2006; 201: 108-119.

Lee DW, Oberbauer SF, Johnson P, Krishnapilay B, Mansor M, Mohamad H, Yap SK. Effects of irradiance and spectral quality on leaf structure and function in seedlings of two Southeast Asian Hopea (Dipterocarpaceae) species. Am J Bot. 2000; 87: 447455.

Maack R. Geografia Física do Estado do Paraná. 2 ed. Rio de Janeiro: J. Olympio; 1981.

Markesteijn L, Poorter L, Bongers F. Light-dependent leaf trait variation in 43 tropical dry forest tree species. Am J Bot. 2007; 94: 515-525.

Niinemets Ü. Components of leaf mass per area thickness and density - alter leaf photosynthetic capacity in reverse directions in woody plants. New Phytol. 1999; 144: 35-47.

Niinemets Ü. The controversy over traits conferring shade-tolerance in trees: ontogenetic changes revisited. J Ecol. 2006; 94: 464-470.

Panditharathna PAKAK, Singhakumara BMP, Griscom HP, Ashton MS. Change in leaf structure in relation to crown position and size class for tree species within a Sri Lankan tropical rain Forest. Botany. 2008; 86: 633-640.

Pearcy RW, Muraoka H, Valladares F. Crown architecture in sun and shade environments: assessing function and trade-offs with a three-dimensional simulation model. New Phytol. 2005; 166: 791-800.

Pearcy RW. Responses of Plants to Heterogeneous Light Environments. In: Pugnair FI, Valladares F, editors. Functional Plant Ecology. 2nd ed. Boca Raton: CRC Press; 2007. p. 212-258.

Poorter L. Growth responses of 15 rain-forest tree species to a light gradient: the relative importance of morphological and physiological traits. Funct Ecol. 1999; 13: 396-410.

Poorter L. Leaf traits show different relationships with species shade tolerance in moist versus dry tropical forests. New Phytol. 2009; 181: 890-900.

Popma J, Bongers F. The effect of canopy gaps on growth and morphology of seedlings of rain forest species. Oecol. 1988; 75: 625-632. 
Rijkers T, Pons TL, Bongers F. The effect of tree height and light availability on photosynthetic leaf traits of four neotropical species differing in shade tolerance. Funct Ecol. 2000; 14: 77-86.

Rondon Neto RM, Kozera C, Andrade RR, Cecy AT, Hummes AP, Fritzsons E, Caldeira MVW, Maciel MN, Souza MKF. Caracterização florística e estrutural de um fragmento de floresta ombrófila mista, em Curitiba, PR - Brasil. Floresta. 2002; 32: 3-16.

Rozendaal DMA, Hurtado VH, Poorter L. Plasticity in leaf traits of 38 tropical tree species in response to light; relationships with light demand and adult stature. Funct Ecol. 2006; 20: 207-216.

Sack L, Melcher PJ, Liu WH, Middleton E, Pardee T. How strong is intracanopy leaf plasticity in temperate deciduous trees? Am J Bot. 2006; 93: 829-839.

Sanches MC, Ribeiro SP, Dalvi VC, Silva MB, Souza HC, Lemos-Filho JP. Differential leaf traits of a neotropical tree Cariniana legalis (Mart.) Kuntze (Lecythidaceae): comparing saplings and emergent trees. Trees Struct Funct. 2010; 24: 79-88.

Santos JHS, Ferreira RLC, Silva JAA, Souza AL, Santos ES, Meunier IMJ. Distinção de grupos ecológicos de espécies florestais por meio de técnicas multivariadas. Rev Árvore. 2004; 28: 387-396.

Vaccaro S, Longhi SJ, Brena DA. Aspectos da composição florística e categorias sucessionais do estrato de três Subseres de uma Floresta estacional Decidual, no município de santa Tereza - RS. Ci Fl. 1999; 9: 1-18.

Valladares F, Niinemets Ü. Shade tolerance, a key plant feature of complex nature and consequences. Annu Rev Ecol Evol Syst. 2008; 39: 237-257.
Valladares F, Sanchez-Gomez D, Zavala MA. Quantitative estimation of phenotypic plasticity: bridging the gap between the evolutionary concept and its ecological applications. J Ecol. 2006; 94: 1103-1116.

Valladares F, Skillman JB, Pearcy RW. Convergence in light capture efficiencies among tropical forest understory plants with contrasting crown architectures: a case of morphological compensation. Am J Bot. 2002; 89: 1275-1284.

Valladares F, Wright SJ, Lasso E, Kitajima K, Pearcy RW. Plastic phenotypic response to light of 16 congeneric shrubs from a Panamanian rainforest. Ecology. 2000; 81: 1925-1936.

Vendramini F, Díaz S, Gurvich DE, Wilson PJ, Thompson K, Hodgson JG. Leaf traits as indicators of resource-use strategy in floras with succulent species. New Phytol. 2002; 154: 147-157.

Vogelmann TC, Nishio JN, Smith WK. Leaves and light capture: light propagation and gradients of carbon fixation within leaves. Trends Plant Sci. 1996; 1: $65-70$.

Witkowski ETF, Lamont BB. Leaf specific mass confounds leaf density and thickness. Oecol. 1991; 88: 486-493.

$\mathrm{Xu} \mathrm{F}$, Guo W, Xu W, Wei Y, Wang R. Leaf morphology correlates with water and light availability: What consequences for simple and compound leaves? Prog Nat Sci. 2009; 19: 17891798.

Received: May 20, 2013; Accepted: January 13, 2014. 